\title{
External Reporting Lines of Academic Special Libraries: A Health Sciences Case Study
}

\author{
Amy G. Buhler, Nita Ferree, Tara T. Cataldo, and \\ Michele R. Tennant
}

\begin{abstract}
Very little literature exists on the nature of external reporting lines and funding structures of academic special libraries. This study focuses on academic health sciences libraries. The authors analyze information gathered from statistics published by the Association of Academic Health Sciences Libraries (AAHSL) from 1977 through 2007; an anonymous online survey of AAHSL library directors; and phone conversations with a select number of directors who were willing to take part in follow-up interviews. The history of changing trends in reporting lines over the years and a view of the diverse arrangements, including strengths and weaknesses, currently existing in academic institutions are examined.
\end{abstract}

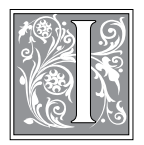

$\mathrm{n}$ academia, the placement of specialized libraries in the organizational structure varies greatly from institution to institution. Do they serve primarily a specific college or academic program, and if so, is this where they should report? Should they report to the main campus library or even to a university official? In this study, we attempt to identify current trends and discover what the differences are in the most common models and what makes a certain model successful in the eyes of the library's director. We will be using academic health science libraries for this exploration. This article will explore in detail the reporting structure of academic health sciences libraries in the United States. We utilized a threepronged approach of data gathering for our analysis: examination of statistics from the Association of Academic Health Sciences Libraries, an online survey of academic health science library directors, and phone interviews with selected directors from various models.

\section{Background \\ Literature Review}

The library and information science literature devotes countless articles to the discussion of the internal organizational structure and management of different types of libraries. ${ }^{1}$ In addition, there is

\footnotetext{
Amy G. Buhler is Engineering Librarian and Associate Chair, Marston Science Library (e-mail: abuhler@ ufl.edu); Nita Ferree is Reference Librarian, Health Science Center Libraries (e-mail: nferree@ufl.edu); Tara T. Cataldo Biological/Life Sciences Librarian, Marston Science Library (e-mail: ttobin@ufl.edu); and Michele $R$. Tennant is Bioinformatics Librarian and Head of Biomedical and Health Information Services, Health Science Center Libraries and UF Genetics Institute (e-mail: tennantm@ufl.edu); all at the University of Florida. (C) Amy G. Buhler, Nita Ferree, Tara T. Cataldo, and Michele R. Tennant
} 
substantial literature that focuses on the management and organizational structure of the library in the larger organization (that is to say, the university). ${ }^{2}$ Articles cover a wide array of topics including the politics of competing for budget with other units in the broader organization, perceptions of effectiveness within the larger organization, and analysis of mergers, primarily those of libraries with Information Technology departments to form information services units or those of public library branches. ${ }^{3}$ However, among this literature we found no article that devoted exclusive or even substantial coverage to the analysis of external reporting relationship or reporting structure of academic libraries or libraries in general. Those that did touch on these issues of interest were either anecdotal in nature or dealt only with corporate, hospital, or public libraries. ${ }^{4}$

Muriel Flower detailed the reporting arrangements of Canadian health sciences libraries (hospital and academic) where there is equal variety in reporting structures among these libraries. According to this 1987 article, "approximately $85 \%$ of U.S. Medical School Libraries report at some level within the health sciences centre, rather than within a library system. ${ }^{5}$ Since that time, this percentage has dropped substantially. James Matarazzo's 2001 article discusses the future of special and research libraries' organizational setting and does touch briefly on the topic of reporting structure by saying: “...there is no single 'optimum' reporting relationship, either now or in the future. If any trend is apparent, it is that these organizations will increasingly use a mix of solid line and matrix reporting relationships that reflects their own unique culture and organizational needs." ${ }^{6}$ Our survey results found that a number of health sciences libraries have dual reporting structures of various sorts.

It became evident from responses to our survey that there is an intrinsic difference in the natures of main campus and health sciences libraries. Searching the literature it was discovered that there is no shortage of articles surveying the background education of, and practices and activities performed by, librarians. However, no articles were found that compared the academic library cultures in depth.

\section{Methods}

Both quantitative and qualitative data are considered in this study. We began our research by analyzing the annual AAHSL statistics. The statistics irregularly included a question on to whom the library reported. We broke down the types of structures reported in the statistics and took note of changing trends over the years.

Next we developed a survey instrument to gather more detailed reporting information from the directors of U.S. health center libraries. The twenty-six question survey (see Appendix A) was approved by the University of Florida's Behavioral/NonMedical Institutional Review Board (IRB-02) and placed online using the software Survey Monkey. An e-mail was sent to the AAHSL Directors' e-mail list with an invitation to participate in the survey. The survey was active for twenty days (June 10-30, 2007). A hiccup in the software forced us to use e-mail for a certain series of questions. Respondents who had self-identified were contacted by e-mail with the follow-up questions.

Participants in the survey were asked if they would be willing to take part in a subsequent telephone interview. Those who agreed gave their names and contact information. All other respondents remained anonymous. After preliminary analysis of the survey results, we chose six respondents for telephone interviews. The interview participants are not identified by name or institution in this paper. None of the interviewees were from the authors' institution. The purpose of these interviews was to gather more qualitative data. These participants represented a variety of reporting structures, some of whom had experienced a change in 


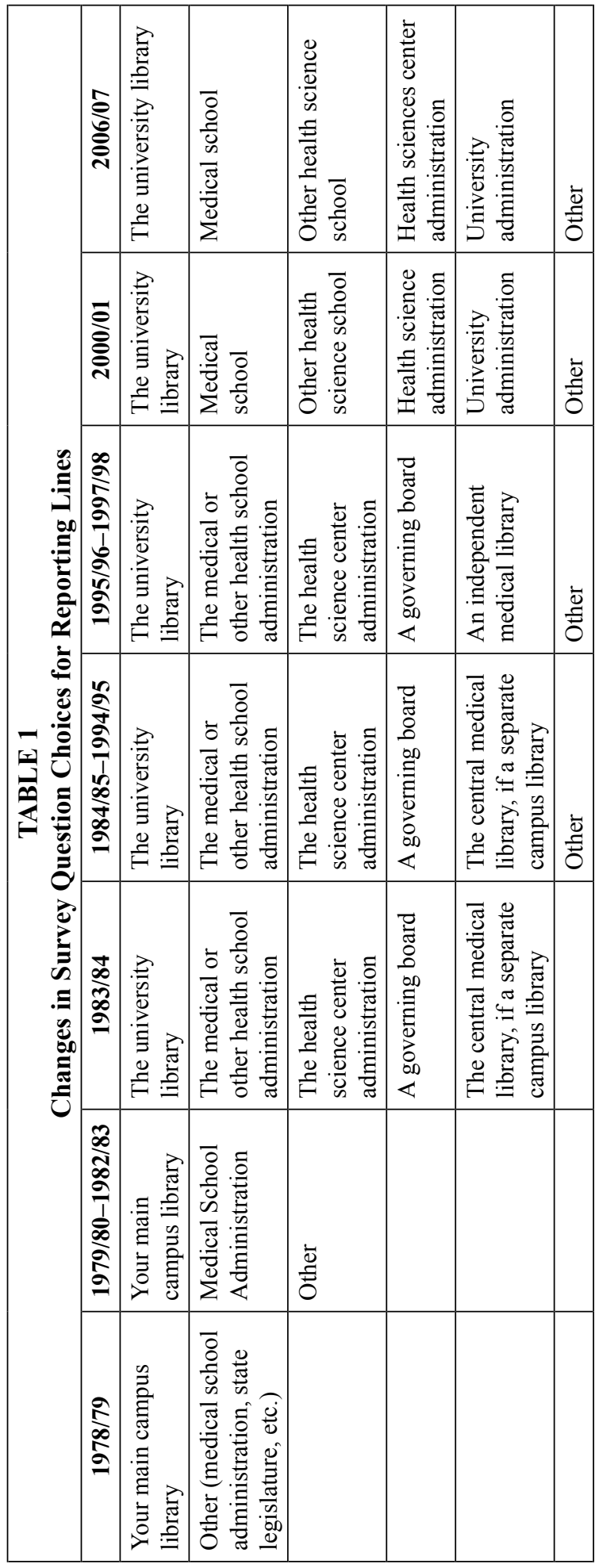

reporting structure during their tenure. The telephone interview questions (see Appendix B) were also approved by the University of Florida's IRB-02. Two authors conducted each interview one asked the questions and one took notes. Five of the six interviewees consented to having their interviews recorded to preserve accuracy; these interviews were later transcribed.

\section{Results and Discussion AAHSL Statistics}

Compiling annual statistics for academic health science libraries began with a national survey conducted by Donald D. Hendricks in the mid-1970s. ${ }^{7}$ The first official survey was conducted by the Association of Academic Health Sciences Libraries (AAHSL) and published as the Annual Statistics of Medical School Libraries in the United States and Canada, 1977-78. ${ }^{8}$ The question about external reporting structures (to whom the directors report) was first included in the second edition (1978-1979). ${ }^{9}$ Possible answers from which the participants could choose were not always consistent throughout the editions, nor was the question included in every year. Table 1 tracks the changes over time.

In the 1978-79 edition of the annual statistics, only two options were offered regarding the reporting question. ${ }^{10}$ The 3rd through the 6th editions, published in 1979-80 through 1982-83, gave three options to those surveyed. ${ }^{11}$ The 1983-84, 7th edition 
offered five choices. ${ }^{12}$ The 8 th edition, covering 1984-85, added the additional option, "other." ${ }^{13}$ These choices remained the same for the next decade (1985-86 through 1994-95, editions 9 though 18). ${ }^{14}$ However, in the 1995-96 survey (19th edition), "central medical library" was replaced by "an independent medical library." ${ }^{15}$ The choices remained constant through the next two editions (the 20th, 1996-97 and 21st, 1997-98). ${ }^{16}$ The 22nd edition (1998-99) ${ }^{17}$ carried this statement: "In 1998-1999 the Editorial Board chose not to survey on type of library... or reporting line. Readers are referred to the 21st edition for this information. As this data changes little from year to year, the Editorial Board will collect type of library and reporting line data in the Quinquennial survey"18 and no reporting information appeared in the 1999-2000, 23rd edition. ${ }^{19}$ Yet, the 24 th edition (2000-01) did contain reporting structure data and made further changes to the categories. ${ }^{20}$ The data were not included in the 25th through the 29th editions (2001-02 through 2005-06). ${ }^{21}$ The survey for the 30th edition (2006-07) offered the same six choices, but changed "health science administration" to "health sciences center administration." 22 The diverse ways in which the data for this particular question were solicited (or not) created a challenge for analysis and coding of the answers longitudinally.

In spite of the challenges, the authors attempted to distinguish the trend in external reporting structures of U.S. academic medical and health science libraries based on the annual AAHSL statistics 1977-78 through 2006-07. Considering only the number of institutions reporting, figure 1 charts the broad trend of external reporting lines of the participating U.S.

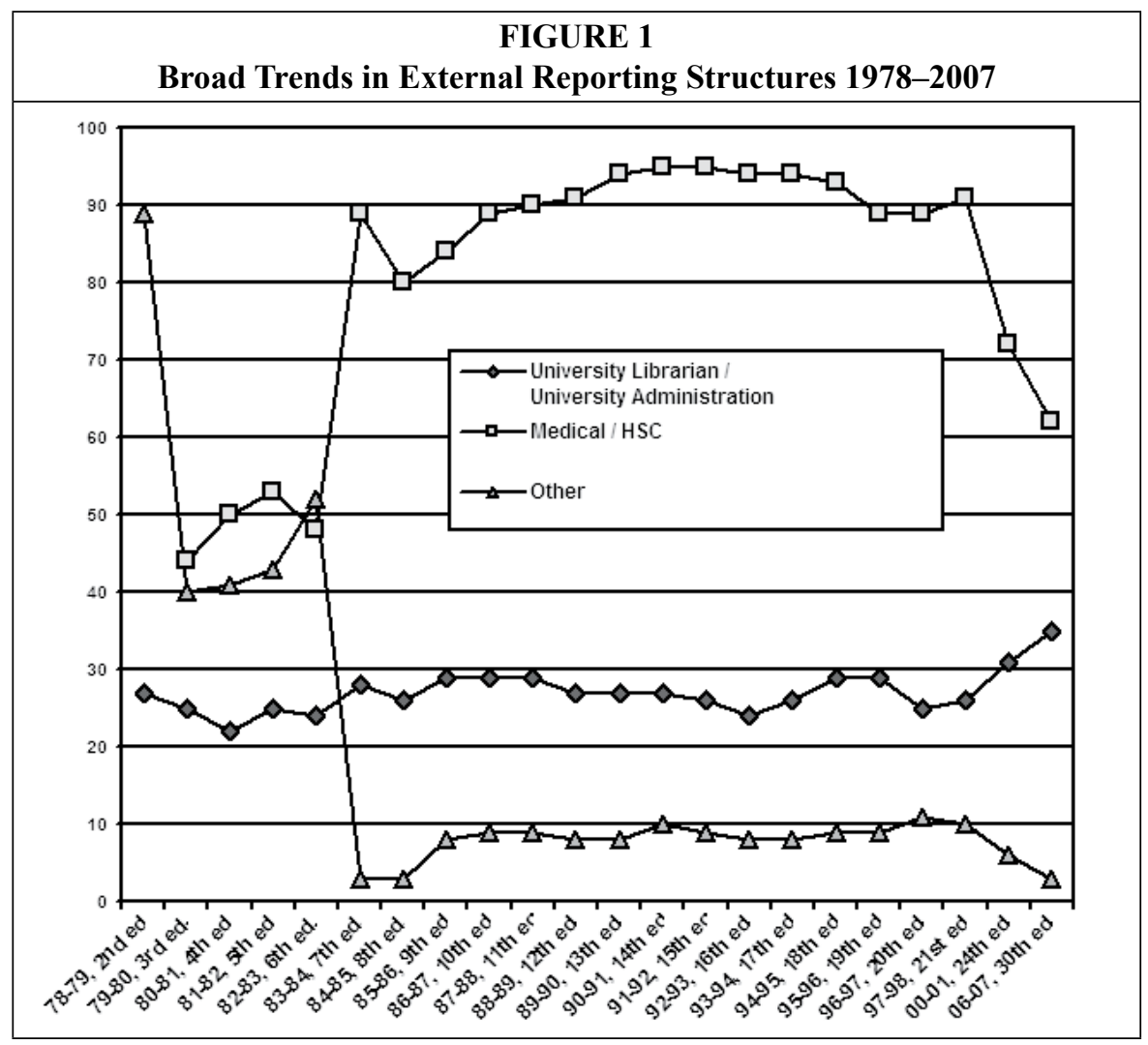




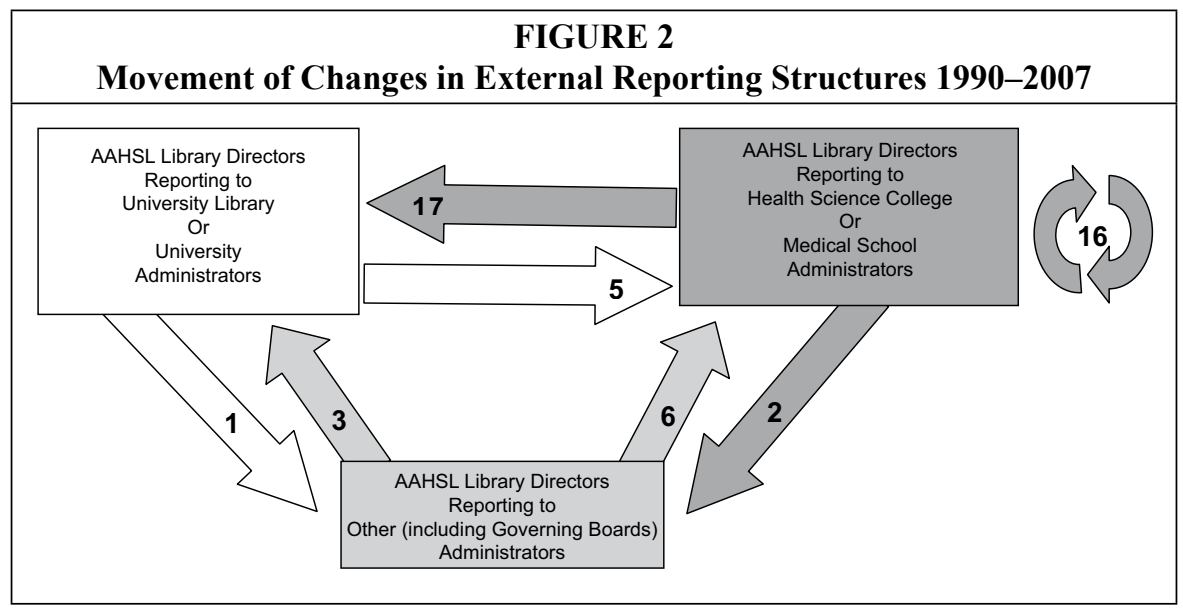

academic medical and health science libraries.

Once the five answer categories were introduced in 1983-84 (7th edition), the figures remained fairly constant until recent years where there appears to be a sharp downturn in the number of directors reporting to medical/health science center personnel, and a slight upswing in those reporting to university administrators. Thus, to study more closely the recent trend, the authors examined the changes that had taken place in the fifty individual institutions that had experienced a change in external reporting structures since 1990. Although several institutions had undergone more than one reporting structure change, for the sake of brevity, only the most recent change was considered.

According to preliminary examination of the statistics, academic health sciences libraries have historically been mainly organized into three types of reporting/ budgetary structures. In the most common model, the library's director reports to a health-related administrator in the health science center or an individual college. The second, less frequently reported model shows the library reporting to someone at the main campus library or a university administrator. The third and least common model consists of those libraries that report to "other" divisions, including a governing board. During the seventeen years from 1990 to 2007, AAHSL surveyed a yearly average of about 124 institutions during which fifty libraries changed from one model to another. Figure 2 illustrates the directionality of change for the thirty-four libraries that converted from one model to another and for the sixteen that switched within the health science center/medical school model. The numbers within each arrow indicate those that changed to that reporting structure.

The online survey and telephone structured interviews were created to understand the reasons for the changes that were not addressed in the annual AAHSL publications.

\section{Online Survey}

Our online survey of AAHSL directors yielded sixty-eight responses out of 140 total members, a response rate of 48.6 percent. Survey results were analyzed to provide the following information:

- Where the directors/libraries report

- Those directors who experienced a change in reporting structure

- Satisfaction with reporting structure

- The level of autonomy in the various reporting lines

- Strengths and weaknesses of the various reporting lines 
- Desire to change reporting structure

\section{Where Do the Directors/Libraries Report} Survey participants were asked to indicate to which part of campus and to what level of administrator they currently reported. Seven category choices were presented:

1. Top Administrator of health science center (Vice President, Vice Provost)

2. Secondary Administrator of health science center (Assistant Vice President)

3. Dean/Director of a health college or school (such as Dean of College of Medicine)

4. Dean/Director of main campus library or libraries (Dean of Libraries)

5. Secondary administrator of main campus libraries (Assistant Director of Libraries)

6. University Administrator (such as Provost)

7. Other (examples: Board of Governors, dual reporting structure)

Figure 3 illustrates the breakdown of these reporting structures.

The sum of the three HSC categories in figure 3 shows 43 percent of the par- ticipating institutions report to someone within the medical or health science center. Combining the next three categories, 42 percent report to either a university librarian or to a university administrator. This would seem to further support what the reporting trends illustrated in figure 1 (taken from AAHSL statistics): that the gap is narrowing and those institutions that report to health/medical divisions are declining, while those reporting elsewhere on campus are on the rise.

\section{Directors Who Experienced Change}

As stated earlier, according to the 19902007 AAHSL statistics, fifty of the libraries had changed reporting structures in those seventeen years, some more than once. In our online survey, twenty-four of the 68 respondents (about 35\%) indicated they changed reporting structures during their tenure as director. Figure 4 details the movement of these reporting structures. Again, the numbers within each arrow indicate those that changed to that reporting structure. There were several changes in reporting structure that occurred within the broad categories. These types of changes are illustrated

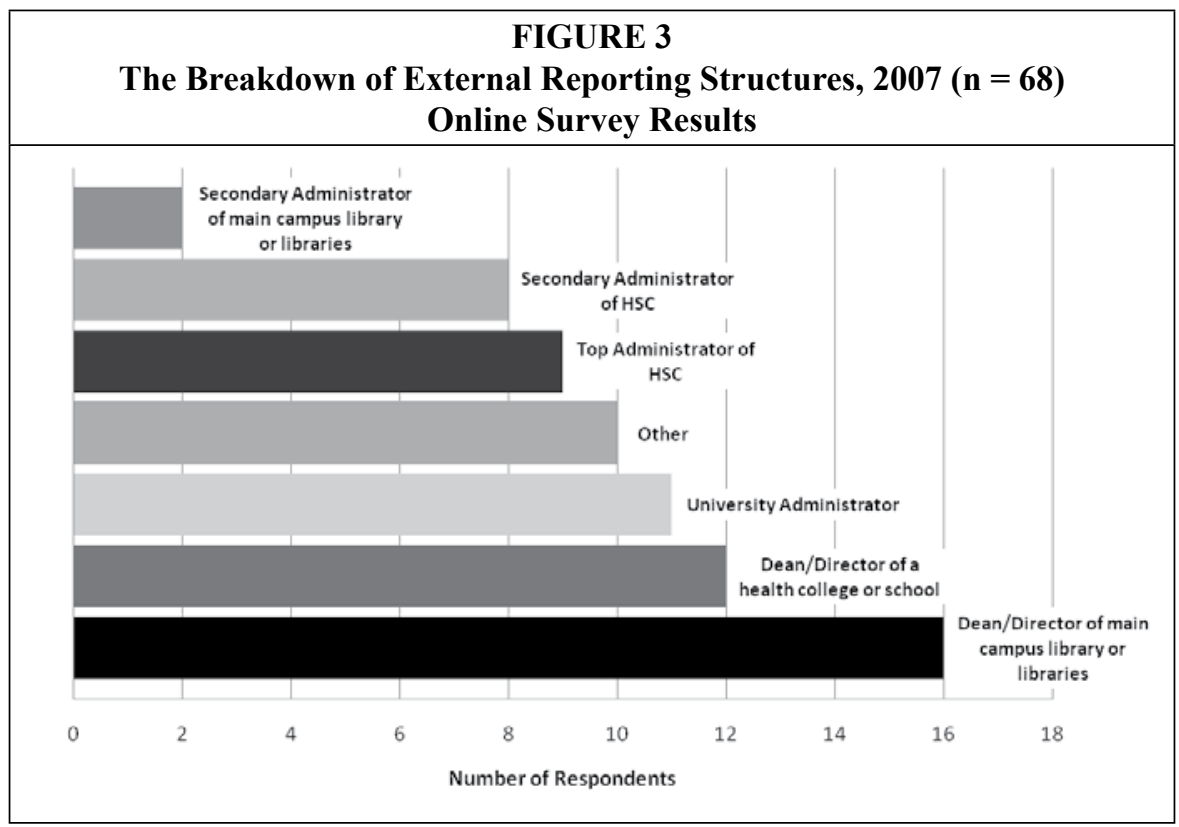




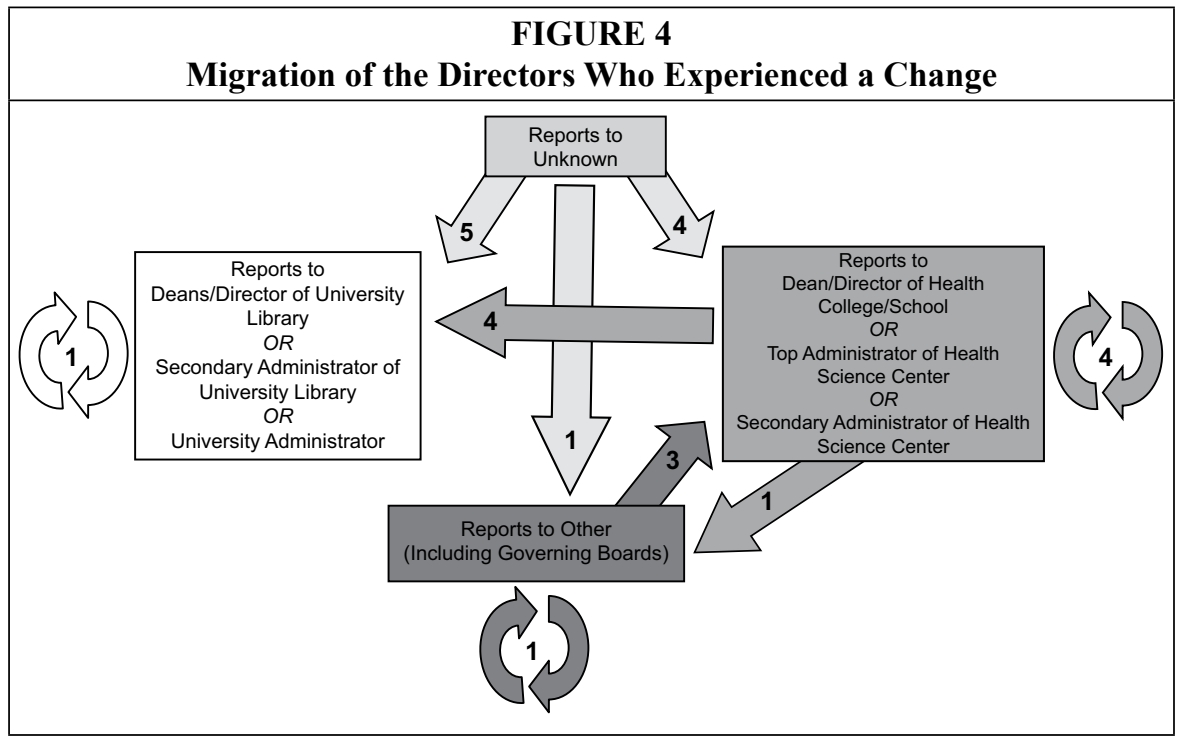

by the circular arrows. Unfortunately, a number of respondents did not indicate to whom they had previously reported; therefore, we had to include the "Reports to Unknown" category.

Respondents were asked what prompted their organization to make a change. A number of factors were listed as reasons for the change in reporting structure; the most frequent reason given (nine times) was the retirement or resignation of the administrator to whom the respondent had reported, or other reorganization of the health center at large. One director did not know why their reporting line had changed, other than the fact that it had been mandated. Other factors, each listed once, included the need to move the library's reporting to a neutral site (now reports to Finance), to increase collaboration and cooperation (to $\mathrm{CIO}$ ), and to get proper support for LCME accreditation (to Dean of Libraries). From these responses, the most common catalyst for library directors' reporting structure change was a structural reorganization or a change in personnel at the health science center or university level.

The directors who changed reporting lines were asked how they viewed the change at the time ("positive," "negative," "neutral"). These responses were compared to the responses from Question 13 ("How satisfied are you with the current reporting structure?") that was asked of all respondents. The one respondent who met the change with a negative viewpoint was not satisfied with the new reporting structure. Of those who viewed the change neutrally (7), 2 were very satisfied, 4 were somewhat satisfied and 1 was not satisfied. Those who viewed the change positively (6) were generally very satisfied with the results (5) with one being somewhat satisfied. Several respondents (9) did not say how they initially viewed

\begin{tabular}{|l|c|c|c|}
\hline \multicolumn{4}{|c|}{ TABLE 2} \\
Satisfaction Level of Directors Who Changed \\
Reporting Structure \\
\hline Currently Reports to & $\begin{array}{c}\text { Very } \\
\text { Satisfied }\end{array}$ & $\begin{array}{c}\text { Somewhat } \\
\text { Satisfied }\end{array}$ & $\begin{array}{c}\text { Not } \\
\text { Satisfied }\end{array}$ \\
\hline $\begin{array}{l}\text { Health Science Center } \\
(\mathrm{n}=13)\end{array}$ & $39 \%$ & $46 \%$ & $15 \%$ \\
\hline $\begin{array}{l}\text { Main Campus } \\
(\mathrm{n}=11)\end{array}$ & $27 \%$ & $46 \%$ & $27 \%$ \\
\hline
\end{tabular}


TABLE 3

The Impact of the Change in Reporting Structure

\begin{tabular}{|c|c|c|}
\hline Type of Change & Positive Impacts & Negative Impacts \\
\hline $\begin{array}{l}\text { Change within Health } \\
\text { Sciences } \\
(\mathrm{n}=10) \\
(30 \% \text { responded "None") }\end{array}$ & $\begin{array}{l}\text { 20\% responded: } \\
\text { - Increased funding } \\
\text { - More influence } \\
\text { 10\% responded: } \\
\text { - Increased staffing } \\
\text { - Building improvements } \\
\text { - Staff raises } \\
\text { - Better communication }\end{array}$ & $\begin{array}{l}\text { 10\% responded: } \\
\text { - Decreased } \\
\text { communication } \\
\text { - Decreased funding } \\
\text { - Decreased staff }\end{array}$ \\
\hline $\begin{array}{l}\text { Change within Main } \\
\text { Campus } \\
(\mathrm{n}=1)\end{array}$ & $\begin{array}{l}\text { 100\% responded: } \\
\text { Expedited processes }\end{array}$ & \\
\hline $\begin{array}{l}\text { Change from Health } \\
\text { Sciences to Main Campus } \\
(\mathrm{n}=4) \\
(50 \% \text { responded "None") }\end{array}$ & $\begin{array}{l}\text { 25\% responded: } \\
\text { - Better technical support } \\
\text { - Better computer support } \\
\text { - Large pool of colleagues } \\
\text { to work with }\end{array}$ & $\begin{array}{l}\text { 50\% responded: } \\
\text { - Difficulty in combining/ } \\
\text { harmonizing policies } \\
\text { 25\% responded: } \\
\text { - Difficulty retaining } \\
\text { independent status }\end{array}$ \\
\hline
\end{tabular}

the change and of these, 1 was very satisfied with the results, 5 were somewhat satisfied and 3 were not satisfied. Table 2 details the satisfaction level of these directors subdivided by reporting location, while table 3 categorizes the paraphrased responses as to the impact of the change. In the tables, the category "Main Campus" includes those reporting to any of the following: dean/director of main campus library or libraries, secondary administrator of main campus libraries, or university administrator. The Category "Health Science Center" includes those reporting to either a top administrator of health science center, a secondary administrator of health science center, or a dean/director of a health college or school.

\section{Satisfaction with Reporting Structure}

In the survey, library directors were asked how satisfied they were with their current reporting structure. Table 4 illustrates reported levels of satisfaction. The numbers for the different reporting structures will vary slightly from those seen in figure 3, which is based strictly on the single survey question. However, further survey information showed that some directors fit in a better category. For example, four of the respondents who chose "other" gave the name of the position as "Associate Dean of [college]." This was considered significant and so broke out in the reporting as "HSC College, Secondary." The analysis of the satisfaction question showed that those reporting to a Top HSC administrator or Top College administrator had the highest level of satisfaction. Those reporting to a Top Library administrator or in the "other" category were the least satisfied. Four out of the five remaining "other" respondents had joint reporting structures (the fifth was to a Board of Governors). All four reported partly to the Dean of Libraries and then two to the Top College, one to the Top HSC, and one to secondary HSC.

Survey respondents were asked to rank their level of satisfaction with current reporting structure among three levels: "very satisfied," "somewhat satisfied," or "not satisfied." Data were then lumped into categories reflecting location of person to whom they reported (HSC, university library, university administrator) and level of administrator (top versus secondary). In all cases (other than the 
disparate "other" category), those directors reporting to the Health Science Center or one of its colleges were more likely to be "very satisfied" (range 50\% to $75 \%$ ) than those reporting elsewhere on campus (range $0 \%$ to $47 \%$ ). The greatest percentage of "very" satisfied directors $(75 \%)$ reported to top administrators of the HSC, while those least likely to be satisfied ( $0 \%$ to $47 \%$ "very satisfied" and $8 \%$ to $20 \%$ "not satisfied") reported to main campus libraries (at least in part) or to a university administrator. When reporting location was grouped regardless of administrator level, those directors who report to the HSC are more likely to be "very satisfied" (69\%) than those who report to main campus (31\%).

Participants were asked to indicate which of four attributes - respect for the library's role in the organization, autonomy, streamlined decisionmaking process, little/no bureaucracy-made their professional relationship with their current supervisor satisfactory. Analysis of the responses can be seen in table 5. Respondents were allowed to choose as many of the four responses as appropriate to their situation. The resultant data were then grouped by reporting type (reports to HSC or main campus) and satisfaction with reporting type (very satisfied or somewhat satisfied). In every instance, autonomy, little/no bureaucracy, and streamlined decision making were chosen by a greater percentage of directors reporting to HSCs than directors reporting to main campus libraries. This pattern held whether directors were "very satisfied" or "somewhat satisfied" with their current reporting structure. The fourth attribute, respect for the library's role in the organization, was evenly distributed among reporting locations with 90 percent of "very satisfied" /" somewhat satisfied" respondents choosing that attribute and is therefore absent from table 5.

While the structure of this question prevents us from stating that the results

\begin{tabular}{|c|c|}
\hline \multicolumn{2}{|c|}{$\begin{array}{c}\text { TABLE } 4 \\
\text { Satisfaction Level }\end{array}$} \\
\hline Reports to & Satisfaction Level \\
\hline $\begin{array}{l}\text { HSC, Top } \\
(n=8) \\
\text { One no response }\end{array}$ & $\begin{array}{l}75 \% \text { Very Satisfied } \\
12.5 \% \text { Somewhat Satisfied } \\
12.5 \% \text { Not Satisfied }\end{array}$ \\
\hline $\begin{array}{l}\text { HSC, } \\
\text { Secondary } \\
(n=8)\end{array}$ & $\begin{array}{l}50 \% \text { Very Satisfied } \\
37.5 \% \text { Somewhat Satisfied } \\
12.5 \% \text { Not Satisfied }\end{array}$ \\
\hline $\begin{array}{l}\text { HSC College, } \\
\text { Top } \\
(n=12)\end{array}$ & $\begin{array}{l}75 \% \text { Very Satisfied } \\
25 \% \text { Somewhat Satisfied } \\
0 \% \text { Not Satisfied }\end{array}$ \\
\hline $\begin{array}{l}\text { HSC College, } \\
\text { Secondary } \\
(n=4)\end{array}$ & $\begin{array}{l}75 \% \text { Very Satisfied } \\
25 \% \text { Somewhat Satisfied } \\
0 \% \text { Not Satisfied }\end{array}$ \\
\hline $\begin{array}{l}\text { Libraries, Top } \\
(n=15)\end{array}$ & $\begin{array}{l}47 \% \text { Very Satisfied } \\
40 \% \text { Somewhat Satisfied } \\
13 \% \text { Not Satisfied }\end{array}$ \\
\hline $\begin{array}{l}\text { Libraries, } \\
\text { Secondary } \\
(\mathrm{n}=2)\end{array}$ & $\begin{array}{l}0 \% \text { Very Satisfied } \\
100 \% \text { Somewhat Satisfied } \\
0 \% \text { Not Satisfied }\end{array}$ \\
\hline $\begin{array}{l}\text { University } \\
\text { Administrator } \\
(\mathrm{n}=13)\end{array}$ & $\begin{array}{l}46 \% \text { Very Satisfied } \\
46 \% \text { Somewhat Satisfied } \\
8 \% \text { Not Satisfied }\end{array}$ \\
\hline $\begin{array}{l}\text { Other } \\
(n=5)\end{array}$ & $\begin{array}{l}80 \% \text { Very Satisfied } \\
0 \% \text { Somewhat Satisfied } \\
20 \% \text { Not Satisfied }\end{array}$ \\
\hline
\end{tabular}

demonstrate that reporting to the HSC increases the four attributes, the results are suggestive. The question, as structured, deals with the attitudes of the person in the manager's position rather than specifically addressing the model. However, the results are clear: those reporting to the HSC report that the positions they are in exhibit these attributes more often than those who report to main campus.

Some participants also provided open-ended responses to this question. A commitment to excellence (two HSCreporting respondents), understanding of library administration and day-to-day operations (two non-HSC-reporting respondents), access to HSC deans and a seat at the table (two HSC, one non-HSC), and an understanding of how HSC libraries are different (one each) were cited 


\begin{tabular}{|l|c|c|c|}
\hline \multicolumn{4}{|c|}{ TABLE 5 } \\
Attributes Analysis \\
\hline Satisfaction Level / Reports to & Autonomy & $\begin{array}{c}\text { Little to No } \\
\text { Bureaucracy }\end{array}$ & $\begin{array}{c}\text { Streamlined } \\
\text { Decision Making }\end{array}$ \\
\hline Very Satisfied, HSC (n=22) & $86.3 \%$ & $50.0 \%$ & $81.8 \%$ \\
\hline $\begin{array}{l}\text { Very Satisfied, Main Campus } \\
\text { (n=12) }\end{array}$ & $58.3 \%$ & $25.0 \%$ & $25.0 \%$ \\
\hline Somewhat Satisfied, HSC ( $=8)$ & $87.5 \%$ & $50.0 \%$ & $62.5 \%$ \\
\hline $\begin{array}{l}\text { Somewhat Satisfied, Main } \\
\text { Campus (n=13) }\end{array}$ & $69.2 \%$ & $23.1 \%$ & $23.1 \%$ \\
\hline
\end{tabular}

as attributes that make the professional relationship satisfactory.

\section{Freedom to Make Decisions}

Survey participants were asked 3 questions regarding their decision-making freedom.

1. Does this line of reporting give you freedom to make budgetary decisions (such as allocations, raises)?

2. Does this line of reporting give you freedom to make administrative decisions (like hiring)?

3. Does this line of reporting give you freedom to make service decisions (for instance, hours open)?

"Response choices were "Yes", "No", "Partially", and are illustrated in Table 6 , subdivided by reporting location and level. Note that in all cases, regardless of level of manager, a higher percentage of HSC-reporting directors find their reporting structure to be amenable to decision-making in all three categories than do those directors reporting to the main campus library."

A second analysis was performed on these data to include the answers "Partially" and "No." This analysis was dubbed the "Power Ranking." "Power Ranking" can be defined as the perceived level of decisionmaking freedom a director possesses, whether high or low. The best possible power ranking was 1 and assigned to those who answered yes to all three questions. The worst power ranking, 10, was for those who answered no to all three questions. The full rankings were as follows.

$\begin{array}{ll}\begin{array}{l}\text { Power } \\ \text { Ranking }\end{array} & \text { Answers } \\ 1 & \text { 3 Yes } \\ 2 & \text { 2 Yes, 1 Partially } \\ 3 & \text { 2 Yes, 1 No } \\ 4 & \text { 1 Yes, 2 Partially } \\ 5 & \text { 1 Yes, 1 Partially, 1 No } \\ 6 & \text { 1 Yes, 2 No } \\ 7 & \text { 3 Partially } \\ 8 & \text { 2 Partially, 1 No } \\ 9 & \text { 1 Partially, 2 No } \\ 10 & \text { 3 No }\end{array}$

The Mean Power Ranking column of table 6 shows average/mean power rankings by reporting type. Note that all categories in which library directors reported to the HSC had the better power rankings (range 1.0-2.0) than did categories in which library directors reported to main campus libraries (range 4.0-5.3). University Administrators also scored well in this area (1.9). These data indicate very strongly that directors of health science libraries who report to the HSC perceive that they have the ability to make decisions pertaining to budget, administration, and services. Directors who report to the main campus library perceive they are less likely to have these abilities.

\section{Strengths and Weaknesses of Reporting Structures}

Respondents were asked to report the greatest strengths and weaknesses of their current reporting model. Answers were binned into themed categories. HSC-reporting directors $(\mathrm{H})$ reported 
10 binned strengths, while those who report to main campus $(\mathrm{M})$ reported 12 . The HSC-reporting directors and the directors reporting to main campus reported the same top three strengths: increased power to access decision makers $(\mathrm{H} 16, \mathrm{M}$ 7), independence/autonomy (H 9, M 4), and their supervisor's cognizance of user needs/library mission (H 6, M 4). Main campus-reporting directors indicated that financial support was a strength of their reporting structure (4), while this was less apparent from HSC-reporting respondents (2). Strengths indicated by HSC-reporting directors but not by their main campus-reporting counterparts include closer ties to the HSC colleges (3) and closer proximity to information technology (1). Strengths indicated by main campus-reporting participants that were not mentioned by their HSC-reporting counterparts included a more neutral position in the organization (3), closer connections to library colleagues (2), more centralized library functions (2), and a more logical tenure and promotion model for librarians (1).

Differences were observed in the reporting concerning weaknesses of Direc- tors' current models. Nine weaknesses were indicated by HSC-reporting directors, while 11 weaknesses were indicated by directors reporting to main campus. Decreased/no access to decision makers (5 respondents) and report to one college but serve many (3 respondents) were cited as weaknesses by those reporting to the HSC. For those reporting to main campus, 9 respondents indicated decreased or no access to decision makers, 6 reported that their libraries are caught in the policies of the main campus library, and 6 reported that the library is no longer linked to the users that it serves. Main campus reporters (but no HSC-reports) noted less autonomy (4) and a competition with the campus libraries for resources (1). Only directors who report to HSC administration stated that there were no weaknesses to their current reporting structure (11 respondents).

The "report to one college serve many"/neutrality issue was of concern to some HSC reporting respondents.

"Since I do report to the School of Medicine, I have to be diligent in

\begin{tabular}{|l|c|c|c|c|c|}
\hline \multicolumn{7}{|c|}{ TABLE 6 } \\
\hline \multicolumn{1}{|c|}{ Reports to } & $\begin{array}{c}\text { Total } \\
\text { Responses }\end{array}$ & $\begin{array}{c}\text { Yes to } \\
\text { Budget } \\
\text { Decisions }\end{array}$ & $\begin{array}{c}\text { Yes to } \\
\text { Administrative } \\
\text { Decisions }\end{array}$ & $\begin{array}{c}\text { Yes to } \\
\text { Service } \\
\text { Decisions }\end{array}$ & $\begin{array}{c}\text { Mean } \\
\text { Power } \\
\text { Ranking }\end{array}$ \\
\hline HSC, Top & 9 & $7(78 \%)$ & $8(89 \%)$ & $7(78 \%)$ & 2.0 \\
\hline HSC, Secondary & 8 & $8(100 \%)$ & $8(100 \%)$ & $8(100 \%)$ & 1.0 \\
\hline HSC College, Top & 12 & $10(83 \%)$ & $12(100 \%)$ & $10(83 \%)$ & 1.3 \\
\hline $\begin{array}{l}\text { HSC College, } \\
\text { Secondary }\end{array}$ & 4 & $4(100 \%)$ & $4(100 \%)$ & $4(100 \%)$ & 1.0 \\
\hline Libraries, Top & 15 & $3(20 \%)$ & $5(33 \%)$ & $7(47 \%)$ & 5.3 \\
\hline $\begin{array}{l}\text { Libraries, } \\
\text { Secondary }\end{array}$ & $\begin{array}{c}2 \text { (only one } \\
\text { answered } \\
\text { decision } \\
\text { questions) }\end{array}$ & $1(50 \%)$ & $1(50 \%)$ & $1(50 \%)$ & 4.0 \\
\hline $\begin{array}{l}\text { University } \\
\text { Administrator }\end{array}$ & 13 & $9(69 \%)$ & $11(85 \%)$ & $11(85 \%)$ & 1.9 \\
\hline
\end{tabular}


making sure I serve the School of Nursing and the hospital as well."

"We serve the health sciences center, but directly report to one of its schools."

It is ironic that, whether reporting to the HSC or main campus, some respondents believe that they are reporting to administrators who do not understand the specific mission of the HSCL (or of libraries in general) and report this as a weakness. Some who report to the HSC indicate that this makes it more difficult to collaborate with other libraries on campus and to meet the needs of all campus library users:

"Tenuous connection with the rest of campus libraries."

"Does not understand greater role in the university and the impact of our decisions, such as budget cuts, on the main campus scientific community."

On the other hand, those who report to the Dean/Director of campus libraries suggested that main campus library administration does not understand the specific needs of health science users and that this compromises service. A number of these respondents wrote lengthy comments to the weaknesses question, including:

"We're not directly linked to those we serve. Our goals, services, and resources can be very different from other academic libraries. We're often caught in policies designed to resolve problems of other campus libraries."

"Every decision I made was reexamined and often overturned to the disadvantage of health sciences users. The significance of health sciences on campus (we are a major research-intensive university) is not recognized."
"Not understood by staff at main library; view us as a branch rather than a special library."

“Centralized library functions ([weakness] same as strengths!), not all needs can be consistent across libraries, HSCLs serve unique, information-hungry constituency."

If changed from main campus report to HSC report: "The needs of the health science libraries would come first and we wouldn't have to go to the level of the lowest common denominator when thinking of new services, etc."

Some respondents suggested that reporting to a Dean of Libraries can cause some confusion concerning their role as advocate:

"There is a track record of favoring improvements on the main campus ... are not vocal enough in support of our library at the deans committee because they assume our university librarian will be the one speaking on behalf of the libraries."

"The main campus library positions itself as 'the' campus library to vendors and others, even for resources where we split the cost-sometimes we must struggle for a seat at the table (annoyance rather than barrier)."

"We gave the university librarian the title of so s/he could speak for all libraries when called for. This created a de facto hierarchy that sometimes trumps general collaboration and my authority."

A weakness that trended through the HSC-reporting respondents related to the level of HSC-administrator to whom they reported. Respondents indicated overall that the level of report 


\begin{tabular}{|l|c|}
\hline \multicolumn{2}{|c|}{ TABLE 7 } \\
Reporting Preference \\
\hline Preferred Administrator & $\begin{array}{c}\text { Number of } \\
\text { Respondents } \\
\text { (n = 16) }\end{array}$ \\
\hline Top administrator of HSC & $6(38 \%)$ \\
\hline University administrator (such as Provost, Vice President) & $6(38 \%)$ \\
\hline Secondary administrator of HSC & $2(13 \%)$ \\
\hline Secondary administrator of main campus library or libraries & $1(6 \%)$ \\
\hline Dean/Director of a health college or school (such as College of Medicine) & $1(6 \%)$ \\
\hline Dean/Director of main campus library or libraries & $0(0 \%)$ \\
\hline
\end{tabular}

was not important in terms of clout, as long as the person that they reported to was a decision maker or had the ear of a decision maker. However, level of report did make a difference in terms of ability to move quickly, a hallmark of health science libraries. Comments from those who reported to a secondary HSC administrator:

"Sometimes we experience delays in making decisions. This is especially true about budgets."

“One more administrative level involved in important decision making. Longer time for decisions to be made/implemented."
Desire to Change Reporting Structure

Of the 68 survey respondents, sixteen $(23.5 \%)$ said they would like to change their current reporting structure. Table 7 illustrates the preference of reporting structure of these sixteen respondents. Not surprisingly, the majority of the respondents reported that they would prefer to report to a top administrator with an even split between a main campus administrator and a health science administrator.

Figure 5 correlates these responses with that individual's satisfaction level. Surprisingly, there were two individuals who reported themselves as very satisfied, yet they had a desire to change their reporting structure. However, it appeared that the changes that they would make

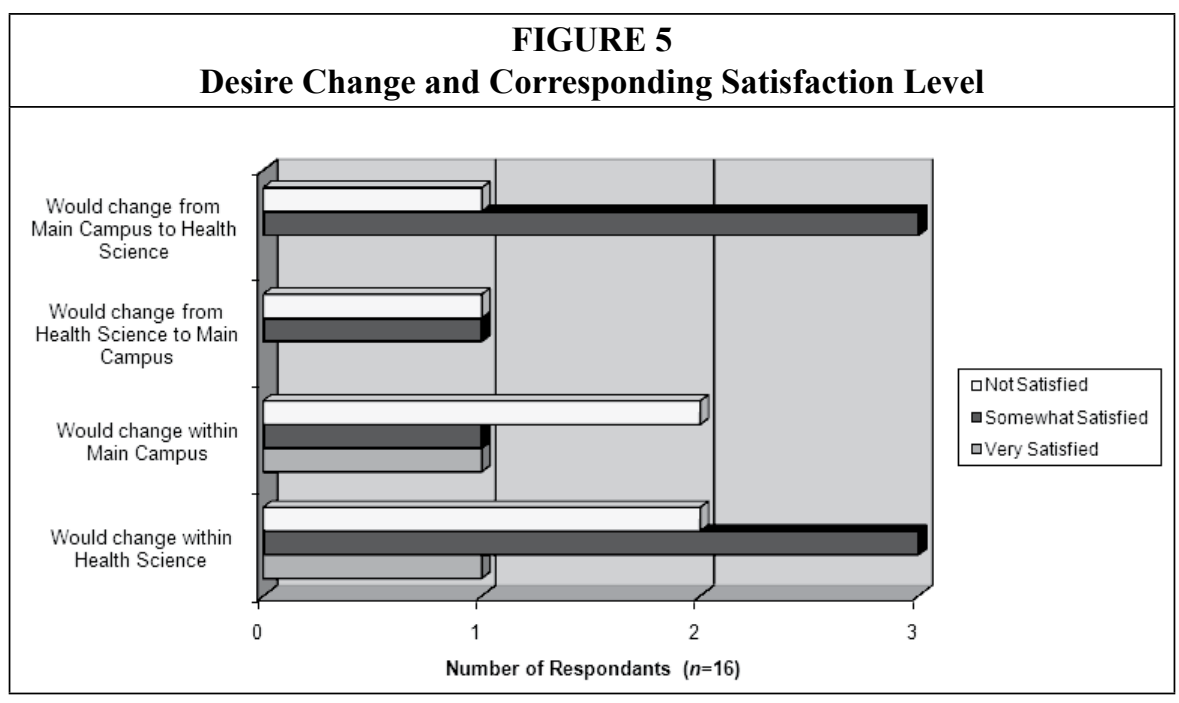


would be relatively minor: that is to say, within the same general organization (within the Health organization or within Main Campus organization).

Respondents were then asked to explain what they saw as the advantages for changing. Each bullet point in table 8 quantifies the comments of the respondents.

All six respondents who wanted to change their reporting structure within the Health Science organization wanted to report to the top administrator of that organization for the primary reasons of visibility and ability to promote the library's agenda at the highest level. Of those who wished to change from Health to Main Campus, one felt that it would be an improvement over reporting to only one of the three colleges that the library served, while the other believed that a higher standard of ethics existed on the Main Campus. Those individuals who desired a change from Main Campus to Health determined that the main reason was more direct alignment with the community that the library served as well as autonomy. The four directors who wanted a change within the Main Campus echoed the desires of those who wanted to change within Health in that they felt reporting to the top administrator of the campus would be the ideal chain of command.

When the perceptions listed in table 8 were compared against the actual advantages (according to individuals who currently had that reporting structure), many similarities arose. Those who wished to report to the top administrator in health science cited direct access and/or communication with health science administration, having a better informational source or "being in the loop," better budget possibilities, and broader influence/perspective. These reasons mirrored the actual advantages reported with the exception of one additional advantage, which was autonomy. Those who wished to report to a secondary administrator cited many of the same perceived advantages (direct/ more interaction, broader perspective, and better budget possibilities), which were echoed by the actual reported advantages in addition to autonomy. Those

\begin{tabular}{|c|}
\hline $\begin{array}{c}\text { TABLE } 8 \\
\text { What Would be the Perceived Advantage of Changing }\end{array}$ \\
\hline Would Change within Health to Top Administrator $(n=6)$ \\
\hline $\begin{array}{l}\text { Would provide: } \\
\text { - More direct line for communication and information flow }(67 \%) \\
\text { - Greater visibility for library in decision making }(50 \%) \\
\text { - A broader perspective }(34 \%)\end{array}$ \\
\hline Would Change from Health to Main Campus $(n=2)$ \\
\hline $\begin{array}{l}\text { Would provide: } \\
\text { - Not just reporting to one of the schools served ( } 50 \%) \\
\text { - Better visibility on campus }(50 \%) \\
\text { - Higher standards of ethics }(50 \%)\end{array}$ \\
\hline Would Change from Main Campus to Health $(n=4)$ \\
\hline $\begin{array}{l}\text { Would provide: } \\
\text { - More direct communication/alignment with the division of health sciences }(100 \%) \\
\text { - Independence from bureaucracy of university library system }(25 \%)\end{array}$ \\
\hline Would Change within Main Campus (n=4) \\
\hline $\begin{array}{l}\text { Would provide: } \\
\text { - More direct line of communication }(75 \%) \\
\text { - Better recognition of user needs }(25 \%)\end{array}$ \\
\hline
\end{tabular}


who wished to report to a Dean/Director within the health sciences again stated the same perceived benefits as did those who currently had that reporting structure. However, this group also noted that a Dean/Director was more accessible to them than a top or secondary administrator would be.

\section{Phone Interviews}

Six library directors were selected from the forty-seven respondents who provided their contact information for follow-up questioning (see Appendix B). Interviews were included in this study to allow a small subset of library directors to elaborate on their survey responses, provide examples, and delve into the "hows" and "whys" that inform their perceptions of reporting structure. Because these interviews were so rich in information, we have included numerous quotes to illustrate the perspectives of these directors. However, given the small sample size (six; even smaller when divided by reporting structure type), these quotes should not be accepted as more than what they are: snapshots of six individual circumstances.

Although the coauthors of this project followed a script with specific questions for these semistructured interviews, there was ample opportunity for follow-up with the interviewees as, for the most part, they were willing to share their experiences very freely. Five of the six interviewees agreed to have their conversations recorded. One interviewee reports to a Top HSC Administrator (THA), one to a Top University Administrator (TUA), two to the Dean/Director of Libraries (DDL), and two had split reporting lines.

\section{Directors Who Experienced Change}

Two interviewees experienced a change in reporting structure during their tenure. Each initially reported to the top administrator of the health sciences until the position was eliminated. From this point, the similarities ended, with one reporting to the TUA and one to the DDL. The interviewee who reported to the DDL was initially asked to make a recommendation about who s/he would like to report to. The director determined that reporting to the Dean of College of Medicine would not be ideal due to the fact that the library served multiple colleges and the fear that the library would be low on the Dean's agenda. In addition, the DDL assured the director that the library would remain independent. Consequently, the director requested to report to the DDL. There was a period when the library was not viewed as independent by a subsequent interim DDL; however, when the new DDL was appointed, s/he indicated that the health sciences library should remain an independent unit.

“...[s/he] said that as far as [s/he] was concerned we were sort of the gold standard of what they were shooting for. We're doing things right. We're doing it at a standard that, you know, they should be doing things and [s/he] said: 'I have no interest in watering that down or disrupting that.' And, so that was very encouraging to me that $[\mathrm{s} / \mathrm{he}]$ respects what we're doing and so forth."

Due to this feedback, this director is "cautiously optimistic" that this model will work.

The biggest challenge to the director who changed to a TUA was a loss of collegiality with the health sciences deans. The director tried to meet this challenge by asking to be appointed to the new larger Deans' Council, which included all the deans on campus as well as the DDL.

"I think I have continued to benefit by being part of the group. Although it's just in a different way. ... I have had to develop other strategies to really strengthen the relationship that I have one-on-one with the deans in HA. ... Well, I don't [feel I still have the same relationship I had with the HA deans that I used to], not as a result of those meetings because they're just too big." 


\section{Satisfaction with Reporting Structure}

The interviewee reporting to a THA was very satisfied with this line. This could be attributed to a high level of autonomy.

\begin{abstract}
"The [THA] does not meet with me often. ... I deal with other people. I deal with the space people on the space. I deal with the budget people on the budget. I deal with the hospital people on the hospital."
\end{abstract}

The interviewee who reported to the TUA was satisfied with the relationship because $\mathrm{s} /$ he was included in all kinds of deliberations that came out of that administrator's office. However, there was some dissatisfaction that the DDL did not act as a spokesperson for all the libraries on campus.

"I felt like it was important to give the University Librarian an opportunity to represent all of our libraries in some cases. Now when we needed to take a position on behalf of the libraries as a whole... That's what I'm not so satisfied with. I mean, I think it's an interesting dynamic. I don't know, maybe it's just an idea that sounds good and doesn't work that well. ... Because we don't have a reporting relationship they don't really know that much about what's going on in the other libraries and I think it's probably only natural that they behave as if they're speaking for their own library. ... [O]ur hope I think was that they might do more collegially to develop plans and positions and opinions on things and you know really, seek to carry out that role on behalf of all of us. And I just think it, you know, we haven't made that work all that well so far."

The directors who report to a DDL were satisfied with some aspects and not with others. One director was satisfied with budget, stating: “... I honestly never have had the budget or would never be given the budget to purchase the amount of electronic resources that we do have. They are purchased centrally, although I'm a major member of the group that does that, it still happens out of the dean's office on main campus." However, both cited dissatisfaction related to harmonization of policies and procedures. One director referred to it as the "big net problem" where "... the main campus will weave a net to solve a problem they have and we get caught in that net. And it's not a problem we have. And so sometimes we have to contort ourselves to sort of deal with their policies and procedures out there." In addition, the other director found the relationship an "awkward arrangement" in terms of collaboration because $s /$ he felt that "... it comes down to if the [DDL] wants it done a certain way that's, I guess, the way it will be. And the [THA] was totally removed from those types of decisions and allowed us to basically run our shop."

Both interviewees with split reporting structures reported to the DDL and an HSC administrator, one to a top level and one to a secondary. One of these directors did not find the structure satisfactory. This was mainly attributed to the Dean/Director of Libraries' lack of understanding. As stated: “The [DDL] really doesn't quite understand the culture of the College of Medicine and that sometimes causes conflict." The other split director found the structure somewhat satisfying claiming, "I have my own budget which is why this works." Both directors received their budgets from the College of Medicine.

\section{Freedom to Make Decisions}

Not surprisingly, the director reporting to the THA had strong input into all decision making. "I don't always get what I want, but I'm not treated any differently than any other dean."

The director reporting to the TUA also had strong input into all decision making. The only area where the director was not purely autonomous was in 
the budget process. All of the libraries at that institution were required to submit a joint budget proposal, but since his/her reporting structure was different, s/he was able to attend the budget presentation with the DDL.

The two directors who reported to the DDL were strong in all three decisionmaking areas, although there were some areas of contention. One was allocation of budget, or more specifically, budget reductions:

\begin{abstract}
"Now, where this becomes sort of tricky for us is when we have budget reductions, which we are doing right now as a matter of fact. So, because [s/he] doesn't know a whole lot about our budget picture here I just sort of get uniform cuts handed to me which are sometimes very difficult for me to accommodate. I mainly get them in two areas-I rarely get them in operations because our operations budget is not huge. I get them in materials, I get them in personnel and it's very hard for me and I explain it over and over. You take away an ILL person from me and you've taken $50 \%$ of my staff where if [s/he] takes an ILL person from main campus [s/he's] taking away $10 \%$ of their staff. So, it's hard for me to convey what these cuts do to me. I say it certainly, but because [s/he] doesn't live with it I don't think I get the same considerations, if that makes sense
\end{abstract}

While the directors with the split reporting structures have some issues with their dual lines, they both feel their input into decision making is strong in all three areas. One admits that the deans have final say on hiring and firing, "but my recommendations are considered strongly."

\section{Professional Relationship and Corresponding Advantages and Disadvantages}

The interviewee who reported to the THA had a good professional relationship with her/his supervisor and felt s/he received "very strong support" for their library. This individual's supervisor took a handsoff approach (often only meeting with her/him on an annual basis), providing the director with an abundance of autonomy. Incidentally, autonomy was cited as both the advantage and disadvantage to this reporting structure.
"We have an opportunity to really initiate things in the library, and develop programs.... The hard part about it is that the hard decisions are ours, too. ... I think it would be very hard for someone [the library director] to come in and navigate in this type of environment where they throw you in and forget about you."

The library director who reported to the TUA described her/his professional relationship as "collegial ... [but] not what I would call a close working relationship." The interviewee met monthly with her/his supervisor through the Dean's Council and then on an "as needed basis." S/he cited the advantage of this reporting structure as "being part of a bigger collegial group" and being seen as a peer to the other deans on campus. Conversely, reporting outside the HSC to other campus administrators had its disadvantages, even when that person was powerful:

\footnotetext{
"The down side is that, I think I had an advocate closer at hand when there was a [THA] position to report to. I think the position I report to now [TUA] is a bigger, more important position, but it's also a more remote position. So, there are ways, you know, strategies for how to deal with that. And I think I've made that work, too. But that's a disadvantage."
}

The two interviewees who reported to the DDL stated that they had a mostly positive professional relationship with 
their supervisor although one felt s/he was neglected, especially when it came to facility issues. One of these directors seemed to have more autonomy than the other in that her/his library was truly viewed as an independent unit.

"As far as I'm concerned, the only thing that's changed here is that I report personally to a different boss. It means nothing in terms of the independent nature of the library system and I've not been told otherwise. So that's how we're going to continue approaching it."

This autonomy was considered a huge advantage since this director had the freedom to remain separate or move in a different direction when it would serve her/his clientele better. The other director cited an advantage of her/his reporting structure was that $\mathrm{s} /$ he also had the health sciences deans to use as leverage to get what $\mathrm{s} /$ he needed from the DDL. One disadvantage cited was the number of differences between the main library and health center library systems (such as user population, services offered, program priorities, classification systems, lending materials).

"So even though ... librarians are librarians, you know when you really break it down, we're a very different breed. So when you're trying to blend those two units, it's not an easy, or I think, really a useful way of doing that."

Both interviewees felt that another important disadvantage was disproportionate representation on library committees.

"But, the fact is you're really a $10 \%$ voice because they're such a large unit and so they'd say: 'Well, you know, that's kind of a cute argument but, in terms of what you're wanting to do, but in our case [campus library] that really doesn't work so, you know, it's $90 \%$ so that's what we're going to do.' So, you know, it really created a lot of conflict and, I think, difficult working relationships were the result of that."

"That's the committee of the dean and all of the library heads and some of the department heads in our main library. And I certainly attend that, but I am one voice on that, so it is really sort of out of whack representationally. Given the amount of work and the amount of transactions that happens in the health sciences library I'm not sure we're fairly represented within the university structure just because we're not a branch and, for the most part, the other libraries they deal with are branches of the main library. But we're not. We're a separate library."

Those directors who had a split reporting structure experienced relatively good professional relationships with their supervisors. They both felt that the fact that their budgets came from the College of Medicine was advantageous. One interviewee who was relatively new to the position appreciated the knowledge base that the DDL possessed and felt comfortable calling on him/her for information about university and library policies. The other interviewee cited staff involvement on committees as an advantage because it was important to collaborate mutually. Disadvantages for these two directors included were as follows:

"A disadvantage is that the dean of the university library doesn't always understand the culture of the College of Medicine and the Health Sciences so there are sometimes decisions that we make that $[\mathrm{s} / \mathrm{he}]$ questions because [s/he] doesn't understand that culture."

"Things take time-have to go off the reservation." 
Those Desiring Change

All interviewees were asked, if given an option, would s/he change the current reporting structure. Those reporting to the THA and the TUA had no interest in changing the reporting structure of their libraries. The two interviewees reporting to a DDL also expressed little interest in changing their reporting structure although perhaps less definitively:

"At this point, I would change if there was a viable person on the Health Science campus to report to. If we did have a Vice President of Health Affairs, that, I think is the best arrangement. Since we don't have that, and we do have now a Dean that appears to recognize, in fact she used to be a medical librarian. So [s/he] certainly understands the issues. And so, I, for the time being, I think that's the best choice that I have available to me."

"I think it would depend so much on what that would be and who would be in place ... we have certainly in the past actually lobbied for that. Didn't come true, but we thought it would solve some problems for us. I'm not so sure I would anymore mainly because of the economics issue. I don't believe the deans in the health science would 'get' what we're facing here in terms of purchasing problems so I think that it would be such a hard battle every year for your budget in the health science environment. I'm not sure that I would want to do that."

Of the directors that had split reports, one desired a change and one did not.

"Yes ... I would in fact if I had my druthers, we have a Vice President for Health Sciences which includes the College of Medicine, College of Nursing and College of Allied Health Professionals and because we support those 3 colleges ideally, I would like to report to that Vice President."

“No. It's complicated. A lot of medical libraries hate it, but that is not the experience at [Institution]. We have our own budget. The university librarian is a good steward and is 'proud of us.'"'

\section{Keeping Connections with Health Science Clientele}

For those Directors who did not report to the HSC Administration, and particularly for those who did in the past but no longer did, keeping a close connection to clients was essential. Directors described how they and their staff managed to do this:

"I found opportunities during the year to work on those relationships, one-on-one. So, I just have an informal goal to try to have, at least once a year, a meeting with each of the deans [of the HSC], if our paths don't cross in other ways - which they often do. But at least it's a 'touch base' meeting with each of those deans, where I can say, 'Is the library giving you the support you need?' and 'What's happening in your school that we might need to know about, that maybe we don't know about?'”

"There is [sic] monthly meetings that the Top HSC Administrator has with [his/her] staff and [his/ her] Deans. ... I don't know if [s/he] really meets regularly with any of the Deans. But, there's always an opportunity to share something there."

"Also, I think that in the last say maybe five years or so, we've developed our library liaison program to be a much stronger program, here. And one of the things that's done for us, I'm not sure we really fully anticipated what impact this would 
have, but I think that it's given other staff in the library who are serving in that role much more of an in-road into things that are happening in the schools. In some cases working directly with the deans themselves. So it isn't just my role. If I had seen that role as, you know, my job to be the eyes and ears on behalf of the library of what's happening that we need to know about, I would have been a failure at that. But because we have other things going on in the library that have given other people a chance to be involved in that effort, I think that's really worked well for us."

\section{Conclusions}

Our examination of the AAHSL statistics indicated a change in the trend of external reporting lines of academic health sciences library directors. Although more institutional directors presently report to a position within the health science center, that number has been declining while the number of those reporting elsewhere on campus has increased. The online survey and telephone interviews supplemented that data with the added dimension of personal experience.

A majority of respondents were "somewhat satisfied" or "very satisfied" related to reporting structure regardless to whom they reported. In fact, the same percentage $(46 \%)$ of respondents are "somewhat" satisfied, whether they report to main campus or the health science center. However, based on the snapshot reported by these respondents, a director is more likely to be "very satisfied" with reporting structure if they report to the health science center, while they are more likely to respond "not satisfied" if they report to the main campus. A greater percentage of directors reporting to HSCs responded that they have autonomy to make budget, administrative, and service decisions. Power rankings (as described in table 6) were more favorable for directors reporting to HSCs than those reporting to main campus libraries, regardless of the level of report. These perceptions by library directors suggest that to whom a HSC library director reports can and does matter.

Ten respondents indicated that being positioned as a "neutral" entity is important to success, especially in an academic health center in which there is more than one college or school served by the HSC library. In most cases, respondents noted the neutrality benefits of reporting to a position such as the "Senior Vice President for Health Sciences" rather than to a dean from one specific college or school. Some respondents indicated that this neutrality issue could be solved by reporting to the dean/director of libraries or other administrator on the main campus. For the most part, the "official" level of administrator to whom a director reports was thought to be less important than the effective clout, interest, and/or knowledge of that person.

In some cases, a "grass is greener" perception was identified. Some directors who report to HSCs believe that reporting instead to a library Dean or Director would be preferable, as these administrators understand libraries, are focused on libraries all day long, and can advocate for libraries. On the other hand, some directors who report outside the HSC believe that reporting instead within the HSC would align them with people who truly understand the missions of the academic health center-educational, research, and clinical.

Based on survey and interview responses, as well as the "water cooler talk" that is pervasive in the profession, medical library directors believe that there are intrinsic differences between the client-base of academic health science libraries and any other library. To serve these clients, the library itself-its mission, priorities, services, librarian and staff knowledge and skill-must be different from those in other libraries to meet those user needs. And, according to these directors, academic health science libraries require the autonomy to meet the needs of these clients. It appears that, for 
many medical library directors, this is the heart of the matter. In the current study, respondents were never specifically asked about these differences; however, thirteen survey respondents independently took the time to indicate in their open-ended responses that these differences exist (unfortunately, most did not actually articulate the differences-they just indicated that medical libraries and their clients are different).

Of further interest is the suggestion by respondents (p. 12,18) that academic medical libraries, even if reporting to the university librarian, are not "branch" libraries. To make the situation more complicated, the respondent on page 12 notes that, instead of a "branch," the medical library is a "special" library. Formal definitions for terms such as "special library" and "branch library" are inconsistent at best. "Special libraries" are generally thought to be libraries with specific subject collections and services aimed at a specialized population. Such libraries may be found within corporations, government agencies, and academic or other institutions..$^{23} \mathrm{~A}$ "branch library," as the name implies, is a division of a larger organization of libraries. Using the definitions above, a library could be described as both "special" and "branch." For example, a science library at a university maintains a specialized collection and performs services for a specific population but is part of the larger campus library organization. An undergraduate library at a college is usually considered a branch library but not a special library. A law firm library is a special library but not a branch library because it is not tied to a larger library organization.

So why is it that those associated with many academic health science center libraries consider their enterprise to be a "special library" but not a "branch library," regardless of reporting structure? While the literature does not provide a coherent explanation, and the current study did not specifically address the "branch" or "not branch" question, the open-ended responses and interviews suggest that the real key is autonomy. No matter the reporting structure, the autonomy to make decisions that are in the best interests of the academic health center's users, rather than the interests of the academic library system as a whole, seems to be a defining feature of the academic health center library. This autonomy allows a logical "separateness," even if the academic medical library is part of a larger whole, and suggests that a more reflective term be coined to describe such libraries.

During the interview phase of this project, one library director made the following distinctions between health science and university libraries:

"Well ... one of the largest issues is that health science libraries and university libraries are very different animals. They have very different populations, and they have very different priorities. If you break down the types of people that we serve, the university campus has ... they have about $95 \%$ of the students. But all of our students are graduate students. So there's a very different mix there.... we have about $45 \%$ of the faculty. ... Then you look at what those faculty and missions are, research is obviously is where our faculty are putting their efforts. And we bring in at least half of the university's grant income. So, you know, there's a heavy focus on that. There are clinical support issues and responsibilities that are not present over in the university libraries and we need to be able to address those as we see fit. And then, also the curriculum is such a different focus. In our case, we're integrated into the medical curriculum with case-based instruction. We do grading and they have to go through a series of modules with us and they have to pass those or face remediation and so forth. So, these are ... key differences between 
what you feel your program priorities are because your population is so different. And that's not even taking into consideration that we have different systems for classifying and organizing and lending materials between the two systems. We have different national ... professional organizations. So even though ... librarians are librarians ... when you really break it down, we're a very different breed."

This is a telling commentary, and follows along the lines of what is commonly discussed among medical librarians. What has confounded this study to some extent is the lack of an integrated literature that specifically states and presents evidence for these differences. The authors of this study believe that research specifically addressing that question would be a fruitful area of study.

Open-ended and interview responses revealed the belief that directing a library can prove to be more challenging if the director's supervisor is not adequately versed in these differences and the issues surrounding health sciences libraries. However, responses indicated that such challenges can be mitigated if administrators provide enough autonomy to their directors (who do understand these differences and issues) to serve their clientele as required by client needs; it matters little if this autonomy is the result of philosophy or "benign" neglect. Some directors who feel removed from their primary clientele based on non-HSC reporting lines have developed a number of ways to keep closely aligned with their users - serving on HSC dean's council, having robust liaison programs serving HSC clients, meeting with HSC deans as needed.

Regardless of reporting relationship, respondents observed that administrators come and go, and such changes in personnel can improve or worsen the reporting relationship and the likelihood of success for the academic health science library. Therefore, it is important that any agreements or protocols that make a relationship successful should be codified to help ensure future success. 


\section{Appendix A: Online Survey of AAHSL Directors}

1. How long have you been in your current position?

$\square \quad$ Less than 2 years

$\square \quad$ More than 2 years, but less than 5 years

$\square \quad$ More than 5 years, but less than 8 years

$\square \quad$ More than 8 years, but less than 10 years

$\square \quad$ More than 10 years

2. To what position in what college, division, or department do you report?

$\square \quad$ Top administrator of health science center

$\square \quad$ Secondary administrator of health science center

$\square$ Dean/Director of a health college/school (such as College of Medicine)

$\square$ Dean/Director of main campus library/libraries

$\square$ Secondary administrator of the main campus library/libraries

$\square \quad$ University administrator (such as Provost, Vice President)

$\square \quad$ Other (please specify)

3. What is the position title of the person to whom you report?

4. Is this the same person who approves your budget?

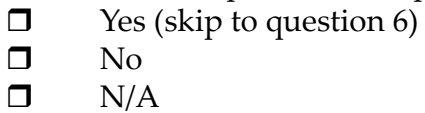

5. What is the title of the position that approves your budget?

6. Has the position you report to changed during your tenure as director?

$\square \quad$ Yes

$\square \quad$ No (skip to question 13)

7. How long ago did this change take place?

8. To what position did you previously report?

$\square \quad$ Top administrator of health science center

$\square$ Secondary administrator of health science center

$\square$ Dean/Director of a health college/school (such as College of Medicine)

$\square \quad$ Dean/Director of main campus library/libraries

$\square$ Secondary administrator of the main campus library/libraries

$\square \quad$ University administrator (such as Provost, Vice President)

$\square \quad$ Other (please specify):

9. What was the position title of the person to whom you reported?

10. Please describe what prompted the change in reporting structure

11. Did you view the change in reporting structure as:
$\square \quad$ Positive
$\square \quad$ Neutral
$\square \quad$ Negative 
12. Please list any major impacts the change had on your library (such as loss/gain of staff, increase/decrease in funding)

13. How satisfied are you with the current reporting structure?

$\square \quad$ Very satisfied

$\square \quad$ Somewhat satisfied

$\square \quad$ Not satisfied (skip to question 15)

14. What attributes make your professional relationship with this position satisfactory? (check all that apply)

$\square$ Respect for the library's role in the organization

$\square \quad$ Autonomy

$\square \quad$ Streamlined decision-making process

$\square \quad$ Little/no bureaucracy

$\square$ Other

$\square \quad$ Other

15. Would you describe your professional relationship with the person to whom you report as:
$\square \quad$ Positive
$\square \quad$ Neutral
$\square \quad$ Negative

16. Does this line of reporting give you freedom to make budgetary decisions (such as allocations, raises)?

$\square \quad$ Yes

$\square \quad$ No

$\square \quad$ Partially (please explain)

17. Does this line of reporting give you freedom to make administrative decisions (such as hiring)?
$\square \quad$ Yes
$\square \quad$ No
$\square \quad$ Partially (please explain)

18. Does this line of reporting give you freedom to make service decisions (such as hours open)?
$\square \quad$ Yes
$\square \quad$ No
$\square \quad$ Partially (please explain)

19. What do you view as the strength(s) of your reporting structure?

20. What do you see as the weakness(es) of your reporting structure?

21. If you could, would you change the current reporting structure?

$\square \quad$ Yes

$\square \quad$ No (skip to question 25) 
22. To whom would you rather report?

$\square \quad$ Top administrator of health science center

$\square \quad$ Secondary administrator of health science center

$\square$ Dean/Director of a health college/school (such as College of Medicine)

$\square$ Dean/Director of main campus library/libraries

$\square$ Secondary administrator of the main campus library/libraries

$\square \quad$ University administrator (such as Provost, Vice President)

$\square \quad$ Other (please specify):

23. What is the position title of the person to whom you would rather report?

24. What would be the advantages of reporting to the position in question 22 and 23 ?

25. Do your librarians have faculty status?

ㄱes, all

$\square \quad$ Yes, some

$\square \quad$ No (skip to question 27)

26. Are your librarians eligible for tenure [on a tenure track]?

$\begin{array}{ll}\square & \text { Yes, all } \\ \square & \text { Yes, some } \\ \square & \text { No }\end{array}$

27. If your anonymity were guaranteed, would you be willing to participate in a brief phone interview?

$\square \quad$ Yes (please fill out information below)

$\square \quad$ No

Name

Library/Institution

You may contact me by calling 


\section{Appendix B: Phone Interview Survey Questions for Health Sciences Directors}

1. In the online survey you indicated you reported to Is this still correct?

(if interviewee indicated in online survey that reporting has changed, ask questions 2--4)

2. How long ago did the change occur?

3. Please describe how your reporting structure changed during your tenure and what were the circumstances that brought about the change?

4. How have staff and librarians responded to the change?

5. How satisfied are you with your current reporting structure?

6. If you could, would you change your current reporting structure?

$\square \quad$ Yes

$\square \quad$ No (skip to question 8)

7. What change(s) would you make?

8. How would you describe your professional relationship with the person to whom you report?

9. Do you feel that your input toward budgetary decisions for the library is strong, adequate, or less than adequate? Is this level of input appropriate for your library?

10. Do you feel that your input toward administrative decisions for the library is strong, adequate, or less than adequate? Is this level of input appropriate for your library?

11. Do you feel that your input toward service decisions for the library is strong, adequate, or less than adequate? Is this level of input appropriate for your library?

12. Could you tell us what you consider to be the advantages and disadvantages of the current reporting structure?

(If librarians are on a tenure track)

13. Does your current reporting relationship support your librarians' effort to gain tenure? Please describe.

$\square \quad$ Yes

$\square \quad$ No

14. Is there anything else you'd like us to know? 


\section{Notes}

1. Joseph F. Boykin and Deborah B. Babel, "Reorganizing the Clemson University Libraries," Journal of Academic Librarianship 19, no. 2 (1993): 94; Peggy Johnson, "Matrix Management: An Organizational Alternative for Libraries," The Journal of Academic Librarianship 16 (1990): 222; Jennifer Cram, "Performance Management, Measurement and Reporting in a Time of InformationCentred Change," Australian Library Journal 45 (1996): 225; Gerald Grant, Shawn McKnight, Aareni Uruthirapathy, and Allen Brown, "Designing Governance for Shared Services Organizations in the Public Service," Government Information Quarterly 24, no. 3 (2007): 522-38; Bill Fisher and Dav Robertson, "Evidence-Based Management as a Tool for Special Libraries," Evidence Based Library and Information Practice 2, no. 4 (2007): 36.

2. S. Paul Petroski, "Redeploying Resources," Journal of the American Society for Information Science 45 (1994): 335.

3. Douglas G. Birdsall, "The Micropolitics of Budgeting in Universities: Lessons.," Journal of Academic Librarianship 21, no. 6 (1995): 427; Eileen McElrath, "Challenges That Academic Library Directors Are Experiencing as Perceived by Them and Their Supervisors," College \& Research Libraries 63, no. 4 (2002): 304; John K. Stemmer, "The Perception of Effectiveness of Merged Information Services Organizations," Reference Services Review 35, no. 3 (2007): 344; Steve McKinzie, "Library and IT Mergers: How Successful Are They?" Reference Services Review 35, no. 3 (2007): 340; Joseph J. Branin and George D'Elia, “The Implementation of the Integrated Information Center at the University of Minnesota," Journal of the American Society for Information Science 48: 442-45; Reference Services Review, Special Issue: Library and IT Mergers 35, no. 3 (2007): 337-514.

4. S. Paul Petroski, "Redeploying Resources," Journal of the American Society for Information Science 45 (1994): 335; Muriel A. Flower, "Libraries without Walls: Blueprint for the Future," Association of Canadian Medical Colleges, Canadian Health Libraries Association, 1987; available online at www.chla-absc.ca/documents/wallsfinal.pdf [Accessed 05 March 2009]; John K. Stemmer, "The Perception of Effectiveness of Merged Information Services Organizations," Reference Services Review 35, no. 3 (2007): 344; Norman Oder, "NYPL Reorganization Coming," Library Journal 132, no. 16 (2007): 12; Anthea Stratigos, "New Roles and Challenges for Info Pros," Online 23, no. 4 (1999): 71.

5. Flower, "Libraries without Walls," 25.

6. James M. Matarazzo, "Bites, Bits, and Video Games: The Changes Ahead," Journal of Academic Librarianship 27, no. 3 (2001): 172.

7. James Shedlock, "The Association of Academic Health Sciences Libraries Annual Statistics: A Thematic History," Journal of the Medical Library Association: JMLA 91, no. 2 (2003): 178-85.

8. Annual Statistics of Medical School Libraries in the United States and Canada. 1st ed. (Houston, Tex.: University of Texas Health Science Center Library, 1977-78).

9. Annual Statistics of Medical School Libraries in the United States and Canada. 2nd ed. (Houston, Tex.: University of Texas Health Science Center Library, 1978-79), 1-4.

10. Ibid.

11. Annual Statistics of Medical School Libraries in the United States and Canada. 3rd ed. (Houston, Tex.: University of Texas Health Science Center Library, 1979-80), 1-4; Annual Statistics of Medical School Libraries in the United States and Canada. 4th ed. (Houston, Tex.: University of Texas Health Science Center Library, 1980-81), 1-2; Annual Statistics of Medical School Libraries in the United States and Canada. 5th ed. (Houston, Tex.: University of Texas Health Science Center Library, 1981-82), 1-2; Annual Statistics of Medical School Libraries in the United States and Canada. 6th ed. (Houston, Tex.: University of Texas Health Science Center Library, 1982-83), 1-2.

12. Annual Statistics of Medical School Libraries in the United States and Canada. 7th ed. (Houston, Tex.: University of Texas Health Science Center Library, 1983-84), 1-2.

13. Annual Statistics of Medical School Libraries in the United States and Canada. 8th ed. (Houston, Tex.: University of Texas Health Science Center Library, 1984-85), 1-2.

14. Annual Statistics of Medical School Libraries in the United States and Canada. 9th ed. (Houston, Tex.: University of Texas Health Science Center Library, 1985-86), 1-2; Annual Statistics of Medical School Libraries in the United States and Canada. 10th ed. Houston, TX: University of Texas Health Science Center Library, 1986-87, 1-2; Annual Statistics of Medical School Libraries in the United States and Canada. 11th ed. (Houston, Tex.: University of Texas Health Science Center Library, 1987-88), 173-74; Annual Statistics of Medical School Libraries in the United States and Canada. 12th ed. (Houston, Tex.: University of Texas Health Science Center Library, 1988-89), 171-72; Annual Statistics of Medical School Libraries in the United States and Canada. 13th ed. (Houston, Tex.: University of Texas Health Science Center Library, 1989-90), 146-47; Annual Statistics of Medical School Libraries in the United States and Canada. 14th ed. (Houston, Tex.: University of Texas Health Science Center Library, 1990-91), 147-48; Annual Statistics of Medical School Libraries in the United States and Canada. 
15th ed. (Houston, Tex.: University of Texas Health Science Center Library, 1991-92), 148-49; Annual Statistics of Medical School Libraries in the United States and Canada. 16th ed. (Houston, Tex.: University of Texas Health Science Center Library, 1992-93), 35-36; Annual Statistics of Medical School Libraries in the United States and Canada. 17th ed. (Houston, Tex.: University of Texas Health Science Center Library, 1993-94), 40-42; Annual Statistics of Medical School Libraries in the United States and Canada. 18th ed. (Houston, Tex.: University of Texas Health Science Center Library, 1994-95), 31-33.

15. Annual Statistics of Medical School Libraries in the United States and Canada. 19th ed. (Houston, Tex.: University of Texas Health Science Center Library, 1995-96), 31-33.

16. Annual Statistics of Medical School Libraries in the United States and Canada. 20th ed. (Houston, Tex.: University of Texas Health Science Center Library, 1996-97), 31-33; Annual Statistics of Medical School Libraries in the United States and Canada. 21st ed. (Houston, Tex.: University of Texas Health Science Center Library, 1997-98), 34-36.

17. Annual Statistics of Medical School Libraries in the United States and Canada. 22nd ed. (Houston, Tex.: University of Texas Health Science Center Library, 1998-99).

18. Ibid., iv.

19. Annual Statistics of Medical School Libraries in the United States and Canada. 23rd ed. (Houston, Tex.: University of Texas Health Science Center Library, 1999-2000).

20. Annual Statistics of Medical School Libraries in the United States and Canada. 24th ed. (Houston, Tex.: University of Texas Health Science Center Library, 2000-01), 57-59.

21. Annual Statistics of Medical School Libraries in the United States and Canada. 25th ed. (Houston, Tex.: University of Texas Health Science Center Library, 2001-02); Annual Statistics of Medical School Libraries in the United States and Canada. 26th ed. (Houston, Tex.: University of Texas Health Science Center Library, 2002-03); Annual Statistics of Medical School Libraries in the United States and Canada. 27th ed. (Houston, Tex.: University of Texas Health Science Center Library, 2003-04); Annual Statistics of Medical School Libraries in the United States and Canada. 28th ed. (Houston, Tex.: University of Texas Health Science Center Library, 2004-05); Annual Statistics of Medical School Libraries in the United States and Canada. 29th ed. (Houston, Tex.: University of Texas Health Science Center Library, 2005-06).

22. Annual Statistics of Medical School Libraries in the United States and Canada. 30th ed. (CDROM) (Houston, Tex.: University of Texas Health Science Center Library, 2006-07).

23. Dictionary.com, Dictionary.com Unabridged (New York: Random House, Inc.), available online at http://dictionary.reference.com/browse/special library [accessed 6 October 2009]; Alma Clarvoe Mitchill, ed., Special Libraries Association, Its First Fifty Years, 1909-1959 (New York: Special Libraries Association, 1959), 4, also available online at www.sla.org/odfs/history/50years_publication.pdf [Accessed 06 October 2009]; International Group of Ex Libris Users, Special Libraries Special Interest Working Group, "Definition, Mission, and Objectives of the Special Libraries SIWG," available online at http://igelu.org/special-interest-working-groups/special-libraries/ objectives [accessed 6 October 2009]. 